\title{
MORPHOLOGICAL ADJUSTMENTS OF THE RADIAL NERVE ARE INTENSITY-DEPENDENT
}

\author{
AJUSTES MORFOLÓGICOS DO NERVO RADIAL SÃO DEPENDENTES DE INTENSIDADE
}

Original Article

AJUSTES MORFOLÓGICOS DEL NERVIO RADIAL SON DEPENDIENTES DE INTENSIDAD

Patrícia Oliva Carbone $e^{1,2}$

(Profissional de Educação Física)

Walter Krause Neto'

(Profissional de Educação Física)

Eliane Florencio Gama'

(Fisioterapeuta)

Wellington de Assis Silva'

(Profissional de Educação Física)

Thatiana Lacerda Nobre ${ }^{2}$

(Fisioterapeuta)

Erico Chagas Caperuto ${ }^{2}$

(Profissional de Educação Física)

Marcelo Betti Mascaro ${ }^{3}$ (Dentista)

Romeu Rodrigues de Souza'

(Médico)

1. Universidade São Judas

Tadeu, Faculdade de Educação

Física, Laboratório de

Estudos Morfoquantitativos e

Imunohistoquímica, São Paulo,

SP - Brasil.

2. Universidade São Judas Tadeu, Faculdade de Educação Física,

Laboratório do Movimento

Humano, São Paulo, Sp - Brasil.

3. Universidade Nove de Julho,

Faculdade de Odontologia,

Departamento de Estudos da

Saúde, São Paulo, SP - Brasil.

\section{Correspondência:}

Walter Krause Neto. Universidade

São Judas Tadeu, Unidade Mooca.

R. Taquari, 546, Mooca, São Paulo,

SP, Brasil. 03166-000.

wild_krause@hotmail.com

\begin{abstract}
Introduction: Peripheral nerve adaptation is critical for strength gains. However, information about intensity effects on nerve morphology is scarce. Objective: To compare the effects of different intensities of resistance training on radial nerve structures. Methods: Rats were divided into three groups: control (GC), training with 50\% (GF1) and training 75\% (GF2) of the animal's body weight. The morphological analysis of the nerve was done by light and transmission electron microscopy. One-way ANOVA and the Tukey's post hoc test were applied and the significance level was set at $p \leq 0.05$. Results: Training groups had an increase of strength compared to GC ( $p \leq 0.05)$. All measured nerve components (mean area and diameter of myelin fibers and axons, mean area and thickness of the myelin sheath, and of neurofilaments and microtubules) were higher in GF2 compared to the other $(p \leq 0.05)$. Conclusion: Results demonstrated greater morphological changes on radial nerve after heavier loads. This can be important for rehabilitation therapies, training, and progression.
\end{abstract}

Keywords: anatomy; neurons; neuroglia; peripheral nerves; resistance training.

\section{RESUMO}

Introdução: A adaptação dos nervos periféricos éfundamental para ganhos de força. No entanto, as informações relativas aos efeitos da intensidade sobre a morfologia do nervo são escassas. Objetivo: Comparar os efeitos de diferentes intensidades de treinamento de resistência sobre estruturas do nervo radial. Métodos: Os ratos foram divididos em três grupos: controle (GC) e treinamento com 50\% (GF1) e 75\% (GF2) do peso corporal do animal. A análise morfológica do nervo foi feita com microscopia óptica e eletrônica de transmissão. A one-way ANOVA e o teste post hoc de Tukey foram aplicados e o nivel de significância foi estabelecido em $p \leq 0,05$. Resultados: Os grupos treinamento tiveram aumento de força com relação ao GC $(p \leq 0,05)$. Todos os componentes medidos do nervo (área média e diâmetro de fibras de mielina e axônios, área média e espessura da bainha de mielina, neurofilamentos e microtúbulos) foram maiores no GF2 em comparação com os demais $(p \leq 0,05)$. Conclusão: Os resultados demonstraram maiores alterações morfológicas no nervo radial depois de cargas mais pesadas. Isso pode ser importante para terapias de reabilitação, treinamento e progressão.

Descritores: anatomia; neurônios; neuroglia; nervos periféricos; treinamento de resistência.

\section{RESUMEN}

Introducción: La adaptación de los nervios periféricos es fundamental para el aumento de fuerza. Sin embargo, la información sobre el efecto de la intensidad sobre la morfología del nervio es escasa. Objetivo: Comparar el efecto de diferentes intensidades de entrenamiento de resistencia en las estructuras del nervio radial. Métodos: Las ratas se dividieron en tres grupos: control (GC) y entrenamiento con 50\% (GF1) y con 75\% (GF2) del peso corporal del animal. El análisis morfológico del nervio se hizo con microscopía óptica y electrónica de transmisión. Se aplicaron la prueba ANOVA de una vía y la prueba post hoc de Tukey y el nivel de significación se fijó en $p \leq 0,05$. Resultados: Los grupos de entrenamiento tuvieron aumento de la fuerza con respecto al grupo control $(p \leq 0,05)$. Todos los componentes medidos del nervio (área media y diámetro de las fibras de mielina y axones, área media y espesor de la vaina de mielina, neurofilamentos y microtúbulos) fueron mayores en GF2 en comparación con los otros grupos $(p \leq 0,05)$. Conclusión: Los resultados mostraron mayores cambios morfológicos en el nervio radial después de las cargas más pesadas. Esto puede ser importante para terapias de rehabilitación, entrenamiento y progresión.

Descriptores: anatomía; neuronas; neuroglía; nervios periféricos; entrenamiento de resistencia.

\section{INTRODUCTION}

Among all exercise programs, endurance (ET) and resistance training (RT) might elicit specific effects on nerve adaptation/regeneration after injury, metabolic imbalance or training ${ }^{1-4}$. ET attenuates oxidative reactions and preserves Schwann cells and myelin sheath from pathologic changes ${ }^{5}$. Meanwhile, RT increases motor unit activation and muscle coordination in well-trained men ${ }^{6}$.

Ladder climbing (LC) training is an effective RT equipment that recruits many muscle motor units and has been shown to be one of the most used training apparatus, possibly recruiting hind limb and forelimb 
muscles $^{7-10}$. Thus, only a few papers published have shown upper limb muscles adaptation to LC or other RT equipment for rodents ${ }^{10}$. Yet, data about upper limb nerve adaptation to RT are scarce.

There is a consensus among authors that positive effects of RT are directly related to intensity, number of sets and rest interval ${ }^{8}$. In accordance, many methods of RT increases muscle strength, partly, due to higher nervous system activity ${ }^{6,11}$ According to American College of Sports Medicine (ACSM) guidelines, intensity above $60 \%$ of the maximum strength capacity must be enough to induce strength gains on health adults. However, many rehabilitation and training centers use lower intensities (Ex. 50\% of the maximum voluntary capacity) to promote muscular strength gains, as most patients might present important co-morbidities which impossibilities then to train with higher loads ${ }^{12,13}$. Meanwhile, during rehabilitation/ training progression, the applicability of heavier training loads may induce a more robust strength gain and nerve plasticity. Nevertheless, until now, no evidence showed the relationship between different intensities of RT and morphological adaptation of peripheral nerves. Our hypothesis is that muscle strength gains accompany the changes in peripheral nerve morphological adaptation.

The aim of the present study was to assess whether different intensities of RT promotes different effects on structural components of the Radial nerve (Rn).

\section{MATERIALS AND METHODS}

This study was approved by the Ethics Committee on Animal Experimentation of the Universidade São Judas Tadeu (USJT) and performed at the Laboratory of Morphoquantitative Studies and Immunohistochemistry (0009/2011). During the experiment, the animals were kept in collective cages (three in each) at controlled room temperature $\left(23^{\circ} \mathrm{C}\right)$ and light-dark cycle (12h light/12h dark). The rats had free access to a diet containing carbohydrate (52\%), protein (21\%) and lipid (4\%) (Nuvilab CR1, Nuvtal Nutrients Ltda, Curitiba, PR, Brazil) and received water ad libitum. We divided 24 young male Wistar rats (three months old) into three groups: GC - animals kept as control of the experiment $(n=8)$, GF1 - animals resistance trained with $50 \%$ of it body weight $(n=8)$ and GF2 - animals resistance trained with $75 \%$ of it body weight $(n=8)$.

\section{Maximum load carrying capacity test and training protocol}

Rodent RT was done using LC, constructed as described by Hornberger and Farrar ${ }^{14}$. Such equipment consisted of a wooden ladder measuring 110 $\mathrm{cm}$ height with metal steps and inclination of 80 degrees (Figure 1A). The animals climbed in order to achieve a rest area at the top of the equipment. No reward or stress was needed to teach the rats to climb the ladder.

The three groups were subjected to maximum load carrying capacity test (MLCC) in a pre- to post-training manner ${ }^{14}$. The MLCC consisted of climbing the equipment with an initial load of $75 \%$ of it body weight. Subsequent increases of 30 grams were done until animal reached "failure". Failure was defined as the animal unsuccessful to climb the apparatus for three consecutive attempts. Load was tied to the animal's tail through a tape attached to a musket (Figure 1B). The animal rested for 120 seconds between each climb attempt. There were no limit of maximum climbs number during the testing period.

GF1 and GF2 groups trained during the morning (11:00am), five times per week and for eight weeks. Each rat in GF1 group performed six climbs with load equals to $50 \%$ of it body weight. The animals of group GF2 performed the same number of climbs, although with $75 \%$ of it body weight. Both groups rest 2 minutes between each climb. The animals in GC climbed the ladder once a day just to pass by the same procedures as animals of the other groups. This procedure was not expected to induce any additional change on the variables to be measured. At the end of each week, animals were weighted and loads adjusted. Total training volume was not equalized because this study aimed to compare each training load effects on nerve adaptation. Therefore, it was applied on purpose. Equally, loading choice (50 and 75\% b.w) was done thinking just on training progression manner and factual comparison.

After final MLCC, the animals were euthanized with an intraperitoneal injection of sodium pentobarbital overdose $(250 \mathrm{mg} / \mathrm{kg})$. Rn fragment of approximately $0.5 \mathrm{~cm}$ long was taken from each animal. These fragments were placed in fixative solution of $2.5 \%$ Glutaraldehyde in phosphate buffer (0.2M, pH 7.3) for three hours. Following, it was washed three times with the same buffer solution for five minutes each time, and subsequently, placed in a solution of Osmium tetroxide in 1\% phosphate buffered for two hours. The fragments remained overnight in 0.5\% Uranyl acetate. Continuing, material was washed with buffer solution and dehydrated in ascending series of alcohol and propylene oxide for eight hours under rotation. The nerves were embedded in pure resin, in such a position that the nerve fibers were cross-sectioned, remaining there for five hours. Finally, in the same resin, it remained for five days. The thin sections were placed on slides and stained with Toluidine blue. After selection of fields, the ultrathin sections were obtained with a diamond knife using an ultramicrotome (Sorvall MT-2, Liverpool, NY - USA). After being contrasted with Uranyl acetate and lead citrate, it was examined in the transmission electron microscope (Jeol, ICB, USP, São Paulo, SP - Brazil). Ten electronic photomicrographs of each nerve were captured by randomly selected fields.

Morphoquantitative analysis was performed using computerized image analysis software (Axio Vision, Zeiss, Germany). In photomicrographs with increased $\times 2000$, we obtained: 1) mean area and diameter of myelinated fibers, 2) mean area and diameter of the myelinated axons, 3) mean area and thickness of myelin sheaths, and 4) average of Schwann cells quantified per area of $64 \mu \mathrm{m}^{2}$. For last, we obtained the mean number of microtubules and neurofilamentos (per area of $125 \mathrm{~nm}^{2}$ ) contained in the cytoplasm of myelinated axons using a final magnification of $x 40000$ (Figure 2). A total of 240 fields were analyzed for each group.

\section{Statistical analyses}

Data were tabulated (mean \pm SD) and compared statistically by one-way ANOVA and post hoc Tukey test. The level of significance was placed as p $\leq 0.05$ (Statistical Package for the Social Sciences, Microsoft, version 21.0, USA).

\section{RESULTS \\ MLCC Test}

Compared to GC, GF1 and GF2 increased carrying load capacity at $53 \%$ and $62 \%$, respectively ( $p \leq 0.05$ ). Further analysis, showed that

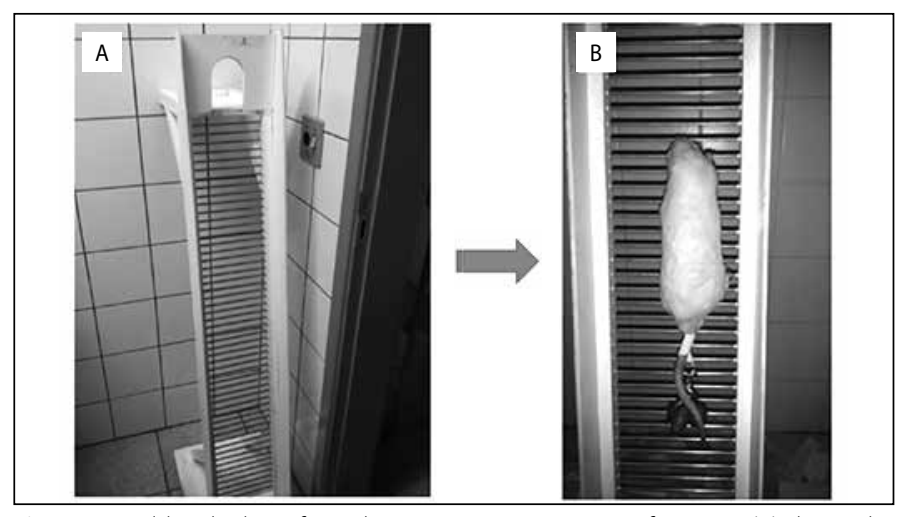

Figure 1. Ladder climbing for rodents resistance training. Left picture (A) shows the training equipment and at right (B) the animal is climbing the ladder with the weight tailed to it. 
GF2 group presented 6\% greater increase than GF1 ( $P \leq 0.05)$. Data are presented in Table I.

\section{Training effect on Rn morphology}

Qualitative analysis showed that GF1 and GF2 presented greater post-training perimeter than GC (Figure 3). All quantitative group comparison are presented in Figure 4.

The average axon areas (mean \pm SD) were $1.1 \pm 0.2 \mu \mathrm{m}^{2}, 1.3 \pm 0.2$ $\mu \mathrm{m}^{2}$ and $2.1 \pm 0.1 \mu \mathrm{m}^{2}$ for GC, GF1 and GF2, respectively. Statistical analysis showed that GF2 promoted a significant $90 \%$ increase compared to GC ( $p \leq 0.05$ ). Axon area of GF1 was $18 \%$ greater than GC, although not significant (Figure 5A). Average diameter of myelinated axons was $1.18 \pm 0.2 \mu \mathrm{m}(\mathrm{GC}), 1.2 \pm 0.2 \mu \mathrm{m}$ (GF1) and $1.8 \pm 0.1 \mu \mathrm{m}$ (GF2). GF2 were statically larger than GC ( $\mathrm{p} \leq 0.05)$.

Average myelin sheath areas were $1.2 \pm 0.2 \mu \mathrm{m}^{2}, 1.5 \pm 0.3 \mu \mathrm{m}^{2}$ and $2.8 \pm 0.1 \mu \mathrm{m}^{2}$ for GC, GF1 and GF2, respectively. GF2 promoted a significant $133 \%$ increase in myelin sheath area compared to GC ( $p \leq 0.05)$. Average area of myelin sheath was 25\% greater in GF1 than GC, however, not significant (Figure 5B). The average thickness of the myelin sheath was $0.4 \pm 0.02 \mu \mathrm{m}$ (GC), $0.42 \pm 0.03 \mu \mathrm{m}$ (GF1) and $0.5 \pm 0.01 \mu \mathrm{m}$ (GF2). GF2 increased mean myelin sheath thickness compared to GC $(p \leq 0.05)$.

The mean area of myelinated fibers were $3.1 \pm 0.1 \mu \mathrm{m}^{2}, 3.6 \pm 0.2$ $\mu \mathrm{m}^{2}$ and $4.5 \pm 0.2 \mu \mathrm{m}^{2}$ for GC, GF1 and GF2, respectively (Figure 5C). GF2 increased average area of myelinated fiber by $45 \%$ compared to $\mathrm{GC}(\mathrm{p} \leq 0.05)$. As for the morphometric analysis, the mean diameter of the myelinated fibers was $1.98 \pm 0.1 \mu \mathrm{m}(\mathrm{GC}), 2.05 \pm 0.2 \mu \mathrm{m}$ (GF1) and $2.8 \pm 0.2 \mu \mathrm{m}(\mathrm{GF} 2)$. Yet, GF2 was larger than $\mathrm{GC}(\mathrm{p} \leq 0.05)$.

The average number of Schwann cells per unit area of $64 \mu \mathrm{m}^{2}$ was used to calculate the total number of Schwann cells. Statistical analysis showed a

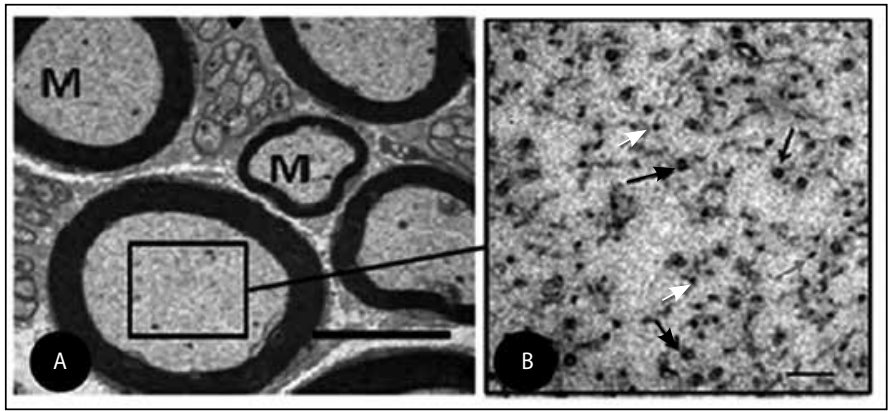

Figure 2. A) Myelinated axon (left) interior part seen with great amplification (right); B) Showing microtubules (black arrows) and neurofilamentos (white arrows) in axon cytoplasm. Bar: a- $10 \mu \mathrm{m} ; \mathrm{b}-0,025 \mu \mathrm{m}$.

Table 1. Pre to post training values (mean \pm SD) from animal's Maximum Load Carrying Capacity in the control (CG) and trained (GF1 and GF2) groups. (grams).

\begin{tabular}{c|c|c|c}
\hline & GC & GF1 & GF2 \\
\hline PRE & $344 \pm 25$ & $351 \pm 17$ & $348 \pm 21$ \\
\hline POST & $356 \pm 15$ & $545 \pm 14^{\mathrm{a}, \mathrm{b}}$ & $579 \pm 20^{\mathrm{a}, \mathrm{b}, \mathrm{c}}$ \\
\hline
\end{tabular}

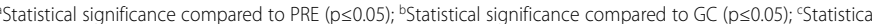
significance compared to GF1 ( $p \leq 0.05)$.

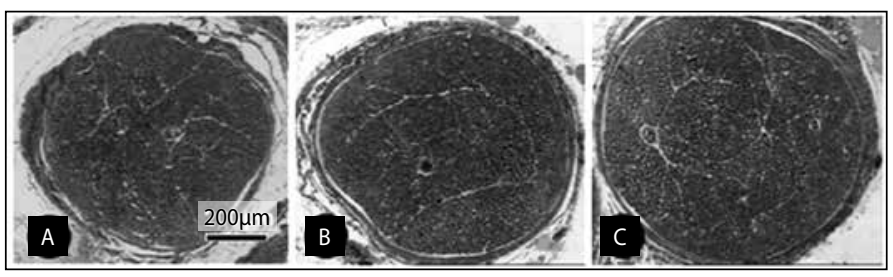

Figure 3. Photomicrographs of the radial nerve histological sections from animals in the control group (A) GF1 (B) and GF2 (C) groups stained with toluidine blue and with the same increase obtained. The nerve of GF2 group (C) shows increased thickness in GF2 (C) group compared to CG (A) and GF1 (B). significant difference between the values of the GF2 (58 cells/field) and GF1 ( 38 cells/field) and between the GF2 and GC ( 37 cells/field) (in both cases, $\mathrm{p}$ $\leq 0.05$ ). There was no significant difference between GF1 and GC (Figure 5D).

The average number of neurofilaments per field was $180 \pm 25,190 \pm$ 20 and $390 \pm 30$ for GC, GF1 e GF2, respectively (Figure 5E). GF2 promoted significant $100 \%$ increase compared to GC ( $p \leq 0.05)$.

The average number of microtubules were $550 \pm 150$ (GC), $580 \pm 110$ (GF1) and $1300 \pm 160$ (GF2). GF2 showed a 136\% increase compared to $G C(p \leq 0.05)$ (Figure $5 F)$.

\section{DISCUSSION}

The main results of this study were; 1) Both training intensities (50\% and $75 \%$ BW) significantly increased muscle strength resistance capacity and 2) Only GF2 (75\% BW) showed significant Rn morphological adaptations. Further, to our knowledge, this is the first study to demonstrate different morphological adaptation on peripheral nerve in face of different training load percentages.

Generally, neural factors play an important role in muscle strength gains. A positive association between the magnitude of efferent neural impulses activation and muscular strength has been demonstrated ${ }^{15}$. Corroborating our findings, many studies presented data about strength gains through different training intensities. Macedo et al. ${ }^{16}$ showed significant muscular strength increases using only $60 \%$ of the rodent maximum voluntary carrying load capacity. Recently, Deus et al. ${ }^{17}$ tested two protocols: Iow (animal body weight) versus moderate-high (75\% B.W to muscle fatigue) training loads. As expected, the author has demonstrated greater carrying capacity through heavier training load. However, a significant and non-expected load (175\%) increase was shown in the low-intensity training group. Clearly, these studies stand the evidence that strength gains might be seen easily during the first weeks of rehabilitation/training. In addition, laboratory rats are often kept in limited size boxes. As consequence, they may have little movement possibilities around environments like this. Therefore, training initiation could explain strength gains in GF1.

Perhaps not expected, the simple action of climbing movement might be enough to induce strength increases. Additionally, many evidence might explain our strength gain findings: 1) increased motor unit recruitment and synchronization; 2) increased motor coordination; 3) increased transmission velocity; 4) increased agonist muscle action and decreased antagonist muscle opposition; 5) increased primary motor muscles electromyography (EMG) activity; 6) increased motor cortex drive; and others ${ }^{18-21}$.

The $\mathrm{Rn}$ is one of the major peripheral nerves of the upper limb, both for it broad area of innervation, either by movements related to it. Peripheral nerves are composed of fibers arranged in fascicles. Therein can be identified myelinated and unmyelinated axons, capillaries, Schwann cell nuclei, interstitial space and other. In transverse sections, the myelinated fibers are of varying sizes. Unmyelinated nerve fibers appeared as a group of small fibers surrounding a Schwann cell. In our study, only GF2 group presented significant morphometric changes as: increased mean axon and myelinated fiber area and diameter, and

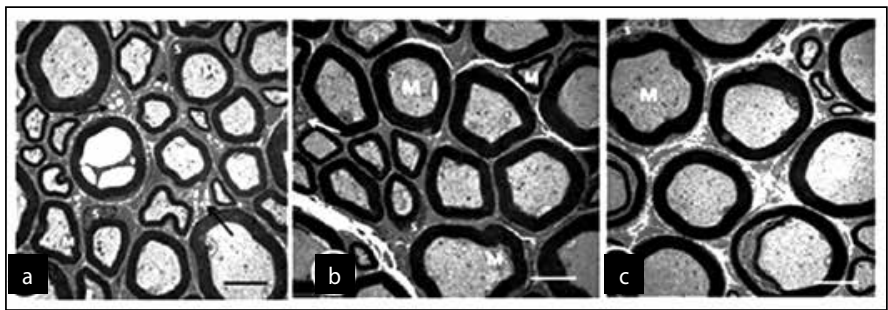

Figure 4. Electronic photomicrographs of the Radial nerve of animals from GC (a), GF1 (b) and GF2 (c) cross-sections, showing unmyelinated (arrows) myelinated fibers (M), and nucleus of Schwann cells (S). Bar: 1 mm. 

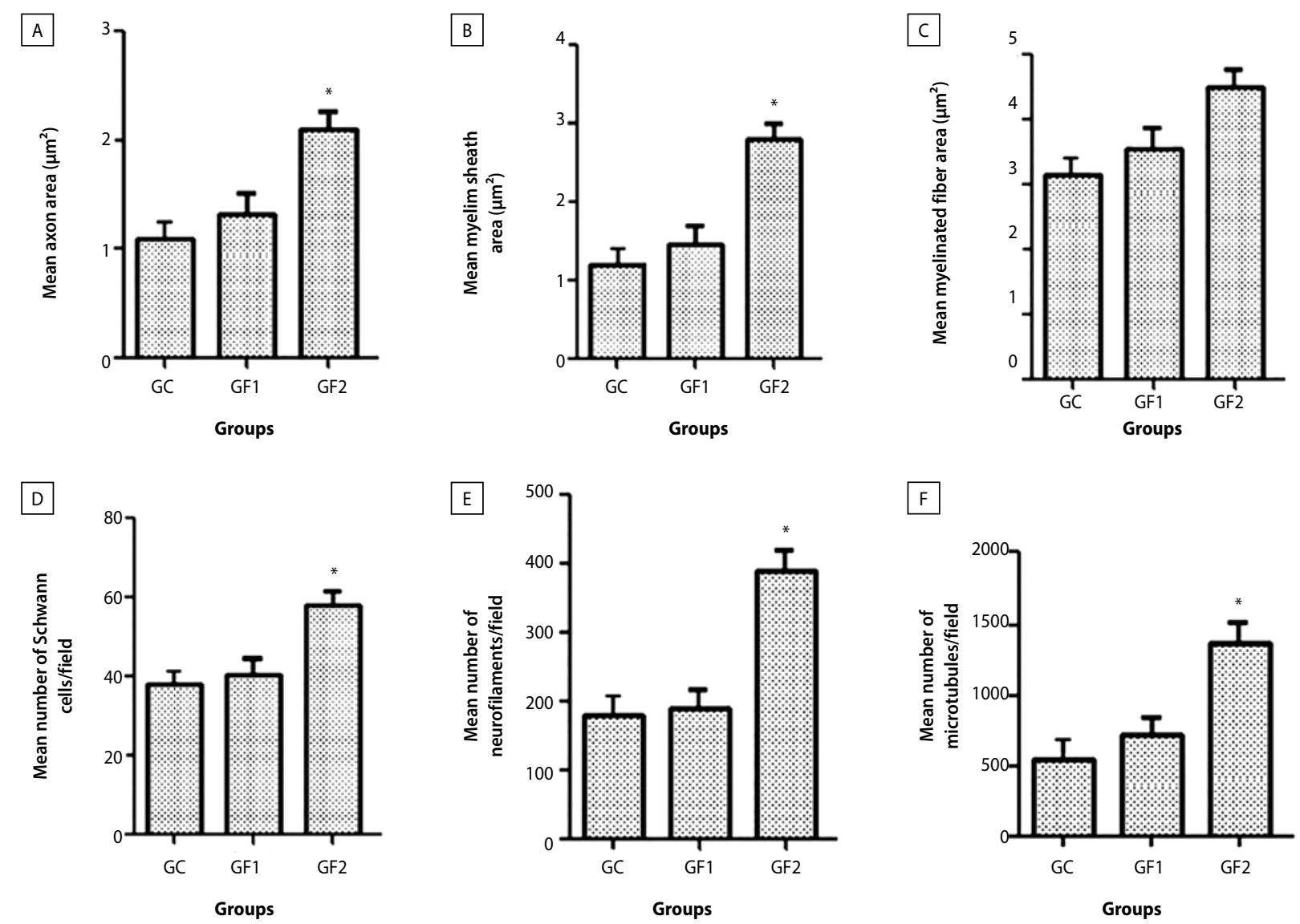

$F$

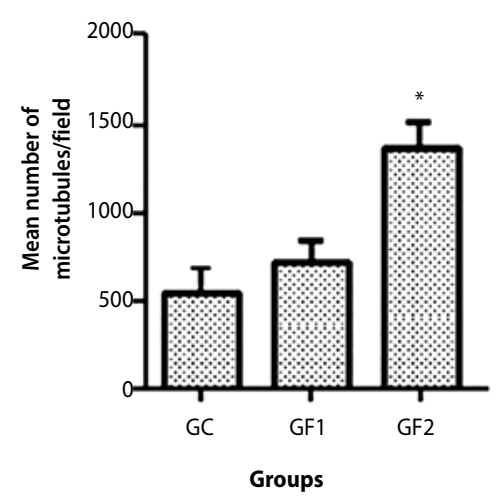

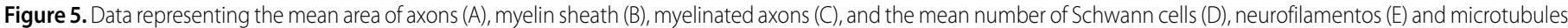

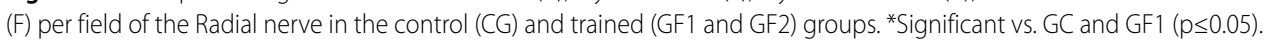

myelin sheath area and thickness. According to Kanda and Hashizume², peripheral nerves can adapt to increased or decreased activity. Literature rises the evidence of several types of exercise training effects on nerve adaptability. However, data on RT effect on nerve morphology is absent. Teodori et al. ${ }^{22}$ showed enlargement of axon and nerve fiber diameter after only 30 days of swimming training, which demonstrated that beginning exercise just after Sciatic nerve injury stimulated nerve repair. On the other hand, Ilha et al. ${ }^{23}$ demonstrated that RT and ET must present different effects on motor function and nerve regeneration. Recently, Cassilhas et al. ${ }^{24}$ investigated the effect of RT and ET on spatial memory and central nervous system signaling pathways. After training, both RT and ET groups showed similar learning and spatial memory improvement. Inversely, both groups presented distinct signaling pathways. RT group increased hippocampal and peripheral insulin like growth factor type 1 (IGF-1) and hippocampal Akt, while ET increased IGF-1, Brain derived neurotrophic factor (BDNF), tyrosine kinase receptor type B (TrkB) and calcium/calmodulin-dependent kinase II ( $\beta$-CaMKII). Yarrow et al. ${ }^{25}$ showed that BDNF might be involved in peripheral nerve plasticity. Wilhelm et al. ${ }^{4}$ postulated that exercise might rule the cooperative action between BDNF and Schwann cells. In these work, the lack of BDNF action did markedly reduced nerve regeneration even in the presence of exercise. Exercise was also found to stimulate peripheral nerve plasticity by activation of Extracellular signal-regulated kinase 1/2 (ERK) mediated Schwann cell proliferation, Fibroblast growth factor-2 (FGF2) gene and lipid peroxidation ${ }^{5,26}$. Unfortunately, all these mechanisms were studied through ET and swimming exercises and perhaps not RT. These cellular and molecular approach was chosen just to add deeply and more robust information to our data as we researched only morphological adaptation.
Each myelinated axon contains numerous neurofilaments and microtubules dispersed in its cytoplasm. Microtubules and neurofilaments are of fundamental importance for the function of the nerves as participates in the processes of plasticity, transport and cell signaling ${ }^{27,28}$. Yet, it determines the caliber, growth pattern, and encourages basic machinery required for both anterograde and retrograde axoplasmic transport ${ }^{29}$. The proteins that make up the neurofilaments are synthesized in the neuron cell body and transported in the axon ${ }^{30}$. Defects in this transport leads to the accumulation of neurofilaments in the cell body and axon, which interferes with the transport of other substances to the distal part of the axon. The present study showed that RT with higher load (75\%BW) increased the density of microtubules and neurofilaments in myelinated axons of the Rn. Although the physical training has increased the neurofilament values, this increase was expected. We do not think that this increase would cause defect in the transport of proteins by the axon. Meanwhile, we did not measure postulated scene. Adaptation of intra cellular proteins seemed to follow the increase in the diameter of the nerve fibers. This result is consistent with Ferreira et al. ${ }^{31}$ who observed that training increased the amount of neurofilament in central nervous axon of rats. The increased density of neurofilaments in GF2 group is consistent with the increase in the area and diameters of myelinated axons observed in this group, since neurofilaments are considered determinants of axon caliber. It is worth mentioning again that although there were morphometric differences in neural adaptations between GF2 and GF1, no such differences in strength gains were noted.

\section{CONCLUSION}


This study demonstrated that nerve of the upper limb might adapt in face of resistance training. However, this data was intensitydependent. This suggests that training and/or rehabilitation centers should take into consideration that the magnitude of the load induces a greater increase in muscle strength and only moderate-intense loadings alter the morphological structure of peripheral nerves.
Furthermore, after beginning with lighter weights the training/ rehabilitation progression with heavier load might be important to induce a more robust adaptation.

All authors have declared there is not any potential conflict of interests concerning this article.

AUTHORS' CONTRIBUTIONS: Each author contributed individually and significantly to the development of the study. POC (0000-0001-5051-3662)* and WKN (0000-0002-68810208)* trained the animals and were the main contributors in writing the manuscript. WAS (0000-0001-6343-5501)*, TLN (0000-0003-1979-9791)*, ECC (0000-0001-7766-7506)* and MBC (0000-0002-7901-5111)* participated in the discussion results and preparation of the manuscript. EFG (0000-0002-9770-8819)* and RRS (0000-0002-3251-276X)* guided the work and participated in the final approval of the article. ${ }^{*} \mathrm{ORCID}$ (Open Researcher and Contributor ID).

\section{REFERENCES}

1. BoeltzT, Ireland M, Mathis K, Nicolini J, Poplavski K, Rose SJ, et al. Effects of treadmill training on functional recovery following peripheral nerve injury in rats. J Neurophysiol 2013;109(11):2645-57.

2. Kanda K, Hashizume K. Effects of long-term physical exercise on age-related changes of spinal motoneurons and peripheral nerves in rats. Neurosci Res 1998;31(1):69-75.

3. Nascimento PS, Lovatel GA, Ilha J, Schaan BD, Achaval M. Diabetes increases mechanical sensitivity and causes morphological abnormalities in the sural nerve that are prevented by treadmill training. Muscle Nerve. 2013:47(1):46-52.

4. Wilhelm JC, Xu M, Cucoranu D, Chmielewski S, Holmes T, Lau KS, et al. Cooperative roles of BDNF expression in neurons and Schwann cells are modulated by exercise to facilitate nerve regeneration. J Neurosci. 2012;32(14):5002-9.

5. Shokouhi G, Tubbs RS, Shoja MM, Roshangar L, Mesgari M, Ghorbanihaghjo A, et al. The effects of aerobic exercise training on the age-related lipid peroxidation, Schwann cell apoptosis and ultrastructural changes in the sciatic nerve of rats. Life Sciences 2008;82(15-6):840-6.

6. Ahtiainen JP, Häkkinen K. Strength athletes are capable to produce greater muscle activation and neural fatigue during high-intensity resistance exercise than nonathletes. J Strength Cond Res. 2009;23(4):1129-34

7. Deschenes MR, Judelson DA, Kraemer WJ, Meskaitis VJ, Volek JS, Nindl BC, et al. Effects of resistance exercise in neuromuscular junction morphology. Muscle Nerve. 2000;23(10):1576-81.

8. Scheffer DL, Silva LA, Tromm CB, da Rosa GL, Silveira PCL, Souza CT, et al. Impact of different resistance training protocols on muscular oxidative stress parameters. Appl Physiol Nutr Metab. 2012;37(6):1239-46.

9. Krause Neto W, Caperuto EC, Gama EF. Resistance training design for animal research: a comparative methodological study. Australian J Basic Applied Sci. 2013;7(14):583-90

10. Nascimento V, Krause Neto W, Gonçalves L, Maifrino LBM, Souza RR, Gama EF. Morphoquantitative analysis revealed triceps brachialis muscle hypertrophy by specific resistance training equipment in rats. J Morphol Sci. 2013;30(4):276-80

11. McBride JM, Blaak J, Triplett-McBride T. Effect of resistance exercise volume and complexity on EMG strength, and regional body composition. Eur J Appl Physiol. 2003;90(5-6): 626-32.

12. Gschwind YJ, Kressig RW, Lacroix A, Muehlbauer T, Pfenninger B, Granacher U. A best practice fall prevention exercise program to improve balance, strength/power, and psychosocial health in older adults: study protocol for a randomized controlled trial. BMC Geriatr. 2013;9;13:105.

13. Tofthagen C, Visovsky C, Berry DL. Strength and balance training for adults with peripheral neuropathy and high risk of fall: current evidence and implications for future research. Oncol Nurs Forum. 2012;39(5): E416-24.

14. Hornberger TAJ, Farrar RP. Physiological hypertrophy of the FHL muscle following 8 weeks of progressive resistance exercise in the rat. Can J Appl Physiol. 2004;29(1):16-31.

15. Guilhem G, Cornu C, Maffiuletti NA, Guével A. Neuromuscular adaptations to isoload versus isokinetic eccentric resistance training. Med Sci Sports Exerc. 2013;45(2):326-35

16. Macedo AG, Krug ALO, Herrera NA, Zago AS, Rush JWE, Amaral SL. Low-intensity resistance training attenuates dexamethasone-induced atrophy in the flexor halluces longus muscle. J Steroid Biochem Mol Biol. 2014;143:357-64.

17. Deus AP, Bassi D, Simões RP, Oliveira CR, Baldissera V, Marquetti RC, et al. A. MMP(-2) expression in skeleta muscle after strength training. Int J Sports Med. 2012;33(2):137-41.

18. Del Balso C, Cafarelli E. Adaptations in the activation of human skeletal muscle induced by short-term isometric resistance training. J Appl Physiol. 2007;103(1):402-11.

19. Gabriel DA, Kamen G, Frost G. Neural adaptations to resistive exercise: mechanisms and recommendation for training practices. Sports Med. 2006;36(2):133-49.

20. Lee M, Gandevia SC, Carroll TJ. Unilateral strength training increases voluntary activation of the opposite untrained limb. Clin Neurophysiol. 2009;120(4):802-8.

21. Pucci AR, Griffin L, Cafarelli E. Maximal motor unit firing rates during isometric resistance training in men. Exp Physiol. 2006;91(1):171-8.

22. Teodori RM, Betini J, Oliveira LS, Sobral LL, Takeda SY, de Lima Montebelo MI. Swimming exercise in the acute or late phase after sciatic nerve crush accelerates nerve regeneration. Neural Plast. 2011;2011:783901.

23. Ilha J, Araujo RT, MalyszT, Hermel EE, Rigon P, Xavier, LL, et al. Endurance and resistance exercise training programs elicit specific effects on sciatic nerve regeneration after experimental traumatic lesion in rats. Neurorehabil Neural Repair. 2008;22(4):355-66.

24. Cassilhas RC, Lee KK, Fernandes J, Oliveira MG, Tufik S, Meeusen R, et al. Spatial memory is improved by aerobic and resistance exercise through divergent molecular mechanisms. Neuroscience. 2012;202:309-17.

25. Yarrow JF, White LJ, McCoy SC, Borst SE. Training augments resistance exercise induced elevation of circulating brain derived neurotrophic factor (BDNF). Neuroscience Lett. 2010;479(2):161-5.

26. Haastert K, Ying Z, Grothe C, Gómez-Pinilla F. The effects of FGF-2 gene therapy combined with voluntary exercise on axonal regeneration across peripheral nerve gaps. Neurosci Lett. 2008;443(3):179-83.

27. Bray D, Gilbert D. Cytoskeletal elements in neurons. Annu Rev Neurosci. 1981:4:505-23.

28. Dent EW, Gertler FB. Cytoskeletal dynamics and transport in growth cone. Motility and axon quidance. Neuron. 2003:40(2):209-27.

29. Monteiro MR, Kandratavicius L, Leite JP. The role of cytoskeleton proteins in normal cell physiology and in pathological conditions. J Epilepsy Clin Neurophysiol. 2011;17(1):17-23.

30. Nixon RA. Dynamic behavior and organization of cytoskeletal proteins in neurons: reconciling old and new findings. Bioessays. 1998; 20(10):798-807.

31. Ferreira AF, Real CC, Rodrigues AC, Alves AS, Britto LR. Short-term, moderate exercise is capable of inducing structural, BDNF-independent hippocampal plasticity. Brain Res. 2011;1425:111-22. 